\title{
A INTERLIGAÇÃO ENTRE PROJETOS DE MOBILIDADE SUSTENTÁVEL COMO VETOR DE RECUPERAÇÃO DO RIBEIRÃO LAVAPÉS NA REGIÃO DE BOTUCATU
}

\author{
Alfredo Paulo Coppini' ${ }^{1}$, Mara Pedroso² e Sirlei Bertolini Soares ${ }^{3}$ \\ 1 Mestrado em Engenharia Agrícola pela Universidade Federal de Lavras. Arquiteto e Urbanista pelo \\ Centro Universitário Belas Artes de São Paulo. E-mail: alfredopaulocoppini@ig.com.br \\ 2 Arquiteta e Urbanista pela Universidade Nove de Julho, do Centro de Engenharia e Cadastro \\ Imobiliário da Procuradoria Geral do Estado de São Paulo-PGE. E-mail: marped_br@uol.com.br \\ 3 Engenheira Civil pela Universidade Mackenzie. E-mail: sirlei_bertolini@hotmail.com
}

\section{RESUMO}

O presente trabalho tem por objetivo analisar a necessidade de investimento na mobilidade sustentável, incentivando os transportes alternativos, especialmente o ciclismo, por meio da implantação e melhoria das ciclovias e ciclo faixas. O mesmo não pretende esgotar o assunto, mas apontar algumas ações responsáveis pelo declínio na qualidade de vida nos centros urbanos e medidas que podem ser adotadas visando promover melhorias nestes ambientes. Entre as possíveis causas da redução da qualidade de vida pode-se mencionar a utilização do veículo particular como principal meio de transporte e sua parcela de responsabilidade como prática bastante nociva que compromete a qualidade da mobilidade e promove a destruição da paisagem nos centros urbanos. Neste sentido, maior ênfase será destinada às vantagens e benefícios da implantação de ciclovias e ciclo faixas. Como estudo de caso, propõe-se reunir alguns dos projetos de ciclovia propostos para o município de Botucatu - em especial o projeto que prevê a implantação de uma ciclovia nas margens do Ribeirão Lavapés - com o intuito de fazer uma interligação em escala regional destes projetos propostos com as trilhas ciclísticas turísticas existentes, utilizadas entre os municípios vizinhos integrantes do "Consórcio Turístico Pólo Cuesta", apontando parcerias entre órgãos públicos, universidade e sociedade para implantação destes projetos de maneira racional e prática, promovendo a mobilidade sustentável numa esfera abrangente.

Palavras-chave: Projeto sustentável. Qualidade Ambiental. Mobilidade Sustentável. Meio Ambiente. Ribeirão Lavapés. 


\title{
INTERCONNECTION BETWEEN SUSTAINABLE MOBILITY PROJECTS AS VECTOR RECOVERY RIBEIRÃO LAVAPÉS IN BOTUCATU REGION
}

\begin{abstract}
This work aims to examine the need for investment in sustainable mobility by encouraging alternative transport, especially cycling, through implementation and improvement of cycle paths and cycle tracks. The same is not intended to exhaust the subject, but to point out some actions responsible for the decline in quality of life in urban areas and measures that can be taken to promote improvement in these environments. Among the possible causes of reduced quality of life may be mentioned the use of private vehicle as the main means of transport and its share of responsibility as a very harmful practice that compromises the quality of mobility and promotes the destruction of the landscape in urban centers. In this regard, greater emphasis will be focused on advantages and benefits of the implementation of bike lanes and cycle tracks. As a case study, proposes to bring together some of the bike lane projects proposed for the city of Botucatu - especially the project comprises the construction of a bike path on the banks of Ribeirão Lavapés - in order to make an interconnection of these projects on a regional scale proposed to the existing tourist cycling trails, used between neighboring municipalities members of the "Consortium tourist Pole Cuesta," pointing partnerships between public, university and society to implement these projects in a rational manner and practice, promoting sustainable mobility in a comprehensive sphere.
\end{abstract}

\section{INTRODUÇÃO}

\section{Mobilidade nos centros urbanos}

Os indivíduos apresentam uma necessidade para se movimentar e desenvolver formas mais rápidas para alcançar lugares distantes. Exemplo emblemático desta condição pode ser visto durante o processo de implantação das ferrovias, a partir do século XIX.

Nos dias atuais uma significativa parcela da população mantém uma preocupação exacerbada voltada para o simbolismo de ascensão social. Neste sentido, o automóvel assumiu posição de indicador de status social e desta forma, muitos de seus 
proprietários sobrepõem a importância dada aos seus veículos à de outros setores voltados para o lazer e cultura, devido aos investimentos financeiros necessários para manutenção ou aquisição de uma enorme quantidade de enfeites, acessórios ou equipamentos para deixar seus veículos cada vez mais personalizados.

Entre as consequências provenientes da popularização do automóvel destaca-se a reorganização urbana - medida necessária para facilitar a expansão da produção - a destruição da paisagem urbana; a precarização e destruição das estradas de ferro; a inviabilização de outros meios de transporte (carroças, bicicletas e caminhadas); os engarrafamentos dos centros urbanos e o aumento de acidentes e mortes causadas por acidentes de trânsito. Todos estes reflexos negativos têm contribuído para que os centros urbanos tornem-se caóticos. Alertas sobre os riscos que o urbanismo moderno, ou melhor, que as práticas urbanísticas modernas ${ }^{1}$ poderiam causar às cidades americanas já eram discutidas em meados do século XX. Durante a década de 1960, a jornalista Janes Jacobs (2000) já apontava que tais preceitos levariam as cidades ao caos absoluto. Para a autora a redução do número de automóveis já se constituía em uma medida profilática para uma melhor qualidade de vida. Ainda sobre o automóvel, Jacobs (2005), considera que seria ele o maior responsável pela destruição das comunidades americanas, eximindo as drogas e a televisão desta posição. A renovação urbana moderna promovia a destruição das comunidades ao devastar antigos bairros para a passagem das highways e expressways e o espaço público perdia sua posição de agente propiciador do encontro de pessoas. A autora cita ainda que em favor da disseminação do automóvel particular, eficientes sistemas de bondes e, posteriormente, de ônibus elétricos foram totalmente desativados. No âmbito da poluição do meio ambiente Jacobs (2005) enfatiza a posição da engenharia e gestão de tráfego, mesmo com todo o seu caráter científico, como responsáveis não apenas pela sua destruição, como também pelo desperdício de tempo, terra e energia.

Outros malefícios causados pelos veículos motorizados estão relacionados à emissão de gases. O transporte motorizado é o setor que mais emite gases nas cidades atualmente, superando em muitos casos até as indústrias. Diariamente toneladas de dióxido de carbono são lançadas pelos escapamentos dos automóveis, sendo que a maioria circulando com uma só pessoa e agravando assim o problema dos conges-

1 Jacobs centrava sua crítica nas propostas da Cidade Jardim, de Ebenezer Howard (1898); na Ville Radieuse, de Le Corbusier (década de 1920) e Daniel Burnham, líder da proposta City Beautiful (JACOBS, 1961). 
tionamentos. Sem levar em conta a liberação de gases como: óxidos de nitrogênio e monóxido de carbono, com maior poder emissão de calor, contribuindo para agravar o aquecimento global.

Diante dos problemas crescentes das cidades, pode-se dizer que recentemente grupos populares passaram a alterar seus hábitos, baseados em necessidades financeiras ou em ideologias ambientais. Assim, o uso dos veículos particulares começou a ser alterado, despontando então, entre estes grupos, a predileção por meios de transportes alternativos, ao particular, como: transporte público, bicicletas ou mesmo aumento dos trajetos percorridos a pé. Acredita-se que estas iniciativas estariam diretamente ligadas à melhoria do quadro caótico dos centros urbanos e que uma boa forma de expandir este pensamento seria por meio da conscientização da população. Entretanto, a participação das autoridades e dos movimentos populares voltados para as campanhas educativas, melhorias de espaços e equipamentos para a circulação em massa ou de pedestres e ciclistas e, principalmente, para o planejamento urbano, seriam fundamentais para o efetivo resultado.

A mobilidade urbana poderia ser entendida como uma das vertentes do conceito de qualidade de vida pública e coletiva. Atendendo as necessidades de versatilidade, economia e qualidade de vida, a bicicleta se colocaria como uma alternativa altamente eficaz. É possível com a adaptação e educação de ciclistas e motoristas organizar e implantar ciclovias e ciclo faixas sem maiores prejuízos ao espaço dos carros, usufruindo o pedalar relativamente seguro e prazeroso, lembrando sempre daqueles que já se utilizam de suas velhas bicicletas como único meio de transporte ao trabalho, muitas vezes, sem qualquer tipo de proteção pessoal, serviços de segurança ou necessidades fisiológicas.

Assim, torna-se necessário desenvolver o sistema ciclo viário - mecanismo para tornar $o$ ato de pedalar uma excelente ferramenta de mobilidade e acessibilidade - de forma eficaz com definição de seus espaços de locomoção, sinalização, fiscalização, estacionamentos, campanhas educativas, linhas de crédito para equipamentos e acessórios de proteção pessoal, áreas de abrangência e integração com outros meios de transporte.

Mesmo com o número de ciclistas aumentando a cada ano, não se percebe uma inserção das melhorias e facilidades destinadas a este público ocorrendo no mesmo ritmo. Noventa e cinco por cento dos acidentes envolvendo ciclistas acontecem em 
cruzamentos ou esquinas (UNESCO), noventa por cento do total de colisões no trânsito são causados por falha humana, onde a maior parte ocorre nos cruzamentos com sinalização adequada tanto vertical como horizontal.

A razão da escassa preocupação do Poder Público em relação ao ciclista está na direção assumida pela política de transporte destes últimos cinquenta anos, completamente voltada à indústria automobilística ${ }^{2}$. No Brasil houve apoio e adesão para que a indústria automobilística se expandisse de forma absoluta.

Um dos maiores entraves para a melhoria das condições de uso da bicicleta como modo de transporte, no Brasil, é a ausência, mesmo com o número de ciclistas crescendo constantemente, de uma demanda e uma representação expressiva. E assim, sem representatividade não há pressão suficiente para que as melhorias comecem a ocorrer de forma ampla. Atualmente a bicicleta tem sido pensada como um elemento separado do sistema de transporte geral. Entretanto, esta ideia ligada a utilização da bicicleta como um modo de deslocamento individual, não estaria afinada com o pensamento que a englobaria como peça de um plano de integração com o transporte existente. Desta maneira, faz-se necessário pensar de forma mais abrangente para que o investimento e a concretização da obra sejam viáveis.

Ao tomar-se, então, o ciclista como elemento de um plano geral de transportes, levase em consideração alguns aspectos conceituais. Assim, define-se segundo código de trânsito brasileiro:

CICLOFAIXA - parte da pista de rolamento destinada à circulação exclusiva de ciclos, delimitada por sinalização específica.

CICLOVIA - pista própria destinada à circulação de ciclos (bicicletas), separada fisicamente do tráfego comum.

As ciclovias e ciclofaixas têm como objetivos: deslocamentos seguros e confortáveis, se integrar com o sistema de transporte estabelecido, aumentar a circulação dentro do bairro, facilitar o acesso aos serviços locais de interesse da população como supermercados, lojas, farmácias, etc.

2 Jacobs (2004) mostra que persistentes ataques corporativos aos sistemas de transportes públicos comandados pela General 
Para a inclusão do ciclista no sistema viário de forma segura e consciente faz-se necessário repensar e rever a sociedade, tanto em seus aspectos relativos às questões educacionais, quanto aos relativos a infraestruturas viárias (ruas, calçadas e pontes). É importante garantir o acesso à ciclovia por caminhos seguros, pois mesmo em países onde as ciclovias já são consideradas tradicionais e fazem parte do sistema geral de transportes ainda ocorrem problemas relativos à invasão dos espaços reservados aos ciclistas por veículos motorizados, principalmente motocicletas. É importante ressaltar ainda que a ciclovia não constitui um local adequado para trânsito de pedestres (caminhadas e corridas), apresentando riscos de conflitos devido à diversidade de uso. Interessante notar, que o surgimento das ciclovias nos países onde o transporte por bicicleta já foi instituído deu-se de forma muito mais vinculada às necessidades de criação e ampliação destes espaços específicos, devido às necessidades e demandas, do que propriamente ligado às questões de segurança.

A bicicleta promove, além de todos os benefícios já citados anteriormente, um deslocamento em diversas ocasiões, mais veloz, que não emite, por si só, gases-estufas. Assim, além de sua contribuição para melhorar a crise de mobilidade urbana, investir na mobilidade via bicicleta é uma forma de permitir o desenvolvimento saudável das gerações futuras. Em termos de investimento, para a empresa que incentiva o uso da bicicleta como transporte para o trabalho ou como parte deste deslocamento para chegar até ele, o retorno pode ser pontuado pela melhora da sua imagem por meio de uma postura responsável na relação com o meio ambiente, diminuição da quantidade de carros no seu estacionamento e na sua vizinhança e redução do sedentarismo de seus funcionários através da prática da atividade física regular.

Desta forma, pode-se dizer que o retorno para a empresa que investe em acessibilidade sustentável é certo. A economia para o investidor que pretende implantar esta política em sua empresa está na redução dos gastos para a saúde e nas melhorias da condição física e psicológica dos funcionários, acarretando menor número de faltas, e maior produtividade. Ao assumir esta postura, a empresa passa a contribuir ativamente com a redução da emissão de $\mathrm{CO}^{2}$, recebendo destaque positivo dentro do sistema empresarial e na mídia. 


\section{A Importância da Educação Ambiental}

A educação ambiental está acima dos interesses particulares e da comercialização da natureza, trabalhando a afirmação de que os recursos naturais e o meio ambiente são "bens comuns" da população local, do país e da humanidade no âmbito geral (LEROY \& PACHECO, 2005). Assim, ela se coloca como ferramenta de gestão dos problemas ambientais.

Os problemas ambientais se manifestam em nível local e em muitos casos, são os residentes da localidade ao mesmo tempo vítimas e causadores de danos, e por isso, são eles, os residentes, aqueles com maior potencial para diagnosticar e resolver a situação. A participação de um grupo local pode ter uma eficiência muito maior do que a do Estado enquanto fiscalizador de cumprimento e controle dos bens públicos (MARCATTO, 2002).

O processo de educação ambiental eficaz procura envolver a população em suas diversas fases. Assim, o envolvimento da população local é de extrema importância na etapa de discussão do problema, diagnóstico da situação local, identificação de possíveis soluções, implementação de alternativas e análise dos resultados. O objetivo da educação patrimonial está centrado na capacitação da população em geral sobre os problemas ambientais e estimular nos participantes o interesse em desenvolver técnicas e métodos em benefício da tomada de consciência sobre a gravidade e urgência dos problemas ambientais (MARCATTO, 2002).

Entre as várias definições dadas à educação ambiental, destacamos a definição dada pela Agenda 21:

(...) desenvolver uma população que seja consciente e preocupada com o meio ambiente e com os problemas que lhes são associados. Uma população que tenha conhecimentos, habilidades, atitudes, motivações e compromissos para trabalhar, individual e coletivamente, na busca de soluções para os problemas existentes e para a prevenção dos novos (...) (CAPÍTULO 36, AGENDA 21)

A definição elucida o caráter central da educação ambiental que está pautado na formação de uma população participativa e atuante, transformadora que busca soluções alternativas para os problemas ambientais. Esta definição está afinada com as 
principais características da Educação Ambiental, definidas na Conferência de Tbilisi, em 1977, enquanto um processo dinâmico integrativo, transformador, participativo, abrangente, globalizador, permanente, contextualizador e também transversal - definido recentemente para as questões ambientais brasileiras. Este sentido transversal propõe que as questões ambientais não sejam tratadas como disciplina específica, mas sim, de forma interdisciplinar com todas as outras disciplinas.

Muitos dos movimentos de oposição e críticas ao modelo de desenvolvimento industrial e seus efeitos econômicos, sociais e ecológicos surgiram durante anos 1970, quando se inicia um processo de tomada de consciência de que os problemas como poluição atmosférica, chuva ácida, poluição dos oceanos e desertificação são problemas universais e urgentes. Neste período inicia-se um questionamento dos conceitos "progresso" e "crescimento econômico". Começam a surgir correntes de pensamento sobre o tema, algumas delas afirmavam que o crescimento econômico e os padrões de consumo da época eram incompatíveis com os recursos naturais existentes. Uma das idéias centrais constituía-se no pensamento de que os seres humanos não só estavam destruindo o meio ambiente, as espécies vegetais e animais, como também se colocando em risco de extinção. Outras procuravam formas de sensibilizar a opinião pública sobre a necessidade urgente de discutir os assuntos ambientais e sociais voltados ao desenvolvimento. Começava a despontar a necessidade de se desenvolver novas bases para o crescimento econômico, compatíveis com a preservação dos recursos naturais existentes. Dentro desse processo dinâmico de discussão, esboçaram-se os conceitos sobre Sustentabilidade e Desenvolvimento Sustentável (MARCATTO, 2002).

Em uma breve explanação sobre a evolução dos conceitos que envolvem a Educação Ambiental, Marcatto (2002), afirma que os problemas ambientais não passaram a existir somente após a Revolução Industrial, mas é evidente que os impactos das ações dos seres humanos foram violentamente aumentados com o desenvolvimento tecnológico e aumento da população mundial provocados por esta Revolução. Sobre os impactos provocados pelo desenvolvimento tecnológico, Morin (2000) afirma que:

O desenvolvimento das ciências trazem-nos progresso, mas também regressões, ajuda uns e mata outros. Os grandes desenvolvimentos desenvolveram tudo e esqueceram-se de desenvolver o conceito de cidadania terrestre. Mas há esperança, tem que haver esperança. Esperamos com esperança com os vários contributos 
das contracorrentes que vão aparecendo por reação às correntes dominantes; - a contracorrente ecológica, que defende a preservação do planeta que é nosso e por isso mesmo não temos o direito de o destruir e simultaneamente de nos destruirmos com ele; a contracorrente qualitativa - que rejeita a filosofia de "quanto mais melhor" e defende a de "quanto melhor melhor" (MORIN, 2000)

Baseando-se na citação de Morin, pode-se depositar nos projetos voltados para a Educação Ambiental, muito da esperança e expectativa de se obter resultados eficazes capazes de reverter, pelo menos em partes, os danos ambientais provocados ao longo dos anos de extração de recursos ambientais e desenvolvimento de tecnologia.

\section{Histórico do Ribeirão Lavapés}

As primeiras concentrações populacionais na região de Botucatu ocorreram próximo do curso d'água do rio, antigamente chamado de Rio da Vila, devido à busca para consumo, pecuária e cultivo de alimentos. A cidade está às margens deste curso que se constitui como um eixo de urbanização da cidade (Fig. 1), pois atravessa toda a cidade de Botucatu. Nota-se que seu volume de água tem diminuído significativamente no decorrer dos anos por degradação da mata ciliar.

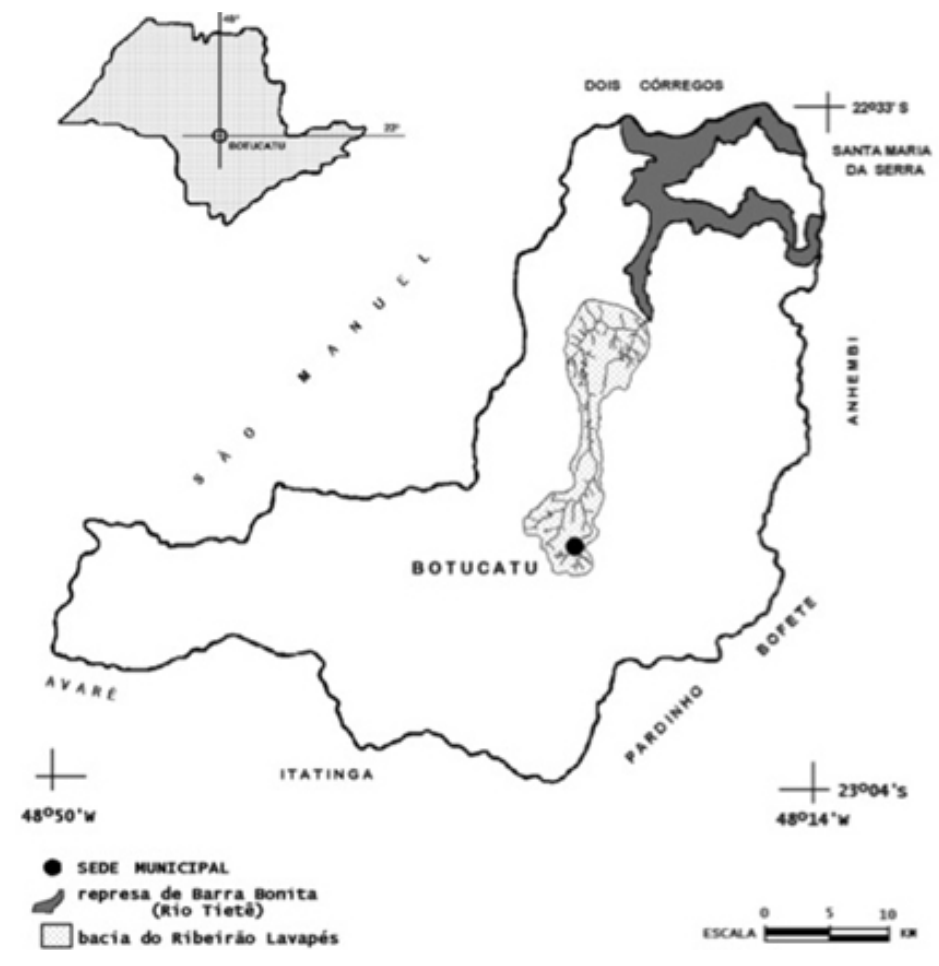

Figura 1: Mapa de localização da bacia do Ribeirão Lavapés 
A deterioração de recursos naturais, principalmente do solo e da água vem aumentando na região de Botucatu devido ao uso da terra sem o planejamento e a utilização dos recursos naturais não renováveis. Com a intensa ocupação das áreas de preservação, coloca-se em risco a estabilidade do solo local e a contaminação da água podendo provocar o assoreamento do rio.

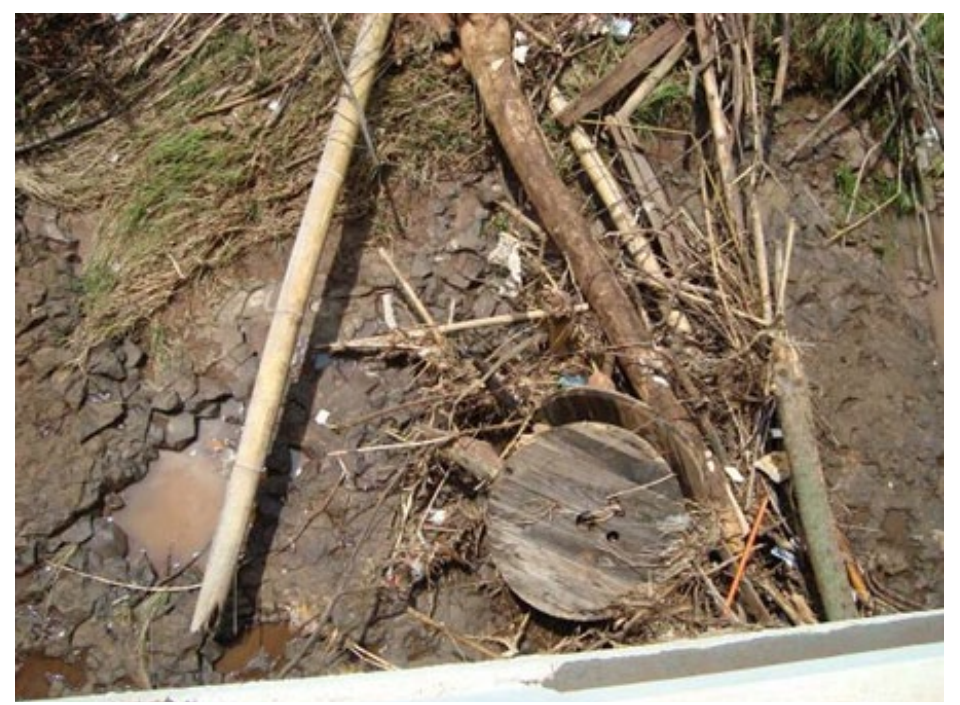

Figura 2: Ribeirão Lavapés perímetro urbano. Fonte: Imagem da autora Mara Pedroso.

Este ribeirão (Fig. 3 e 4), um dos importantes rios formadores da bacia do Rio Pardo, atravessa o campus da UNESP Lageado de Botucatu, onde está instalada a Faculdade de Ciências Agronômicas (FCA), a Fundação de Estudos e Pesquisas Agrícolas e Florestais (FEPAF), uma Fazenda Experimental de Ensino Pesquisa e Produção (FEPP) e Núcleo de Estudos e Práticas Pedagógicas (NEPP). Este Campus teve o privilégio de ser implantado no terreno onde se situa um importante patrimônio histórico de Botucatu, a Fazenda Lageado, que atrai muitos turistas e está em processo de revitalização para recuperação e preservação da própria história e patrimônio físico e cultural. Entretanto, está em busca de alternativas sustentáveis para manutenção de seu crescimento.

O Campus Lageado da UNESP concentra moradia para alunos e professores e faz experimentos "in loco" como o "Sítio Modelo" que tem o objetivo de ser "um modelo de exploração sustentável voltado à agricultura familiar, como espaço de capacitação, treinamento e desenvolvimento de tecnologias para pequenos produtores rurais e assentados". 

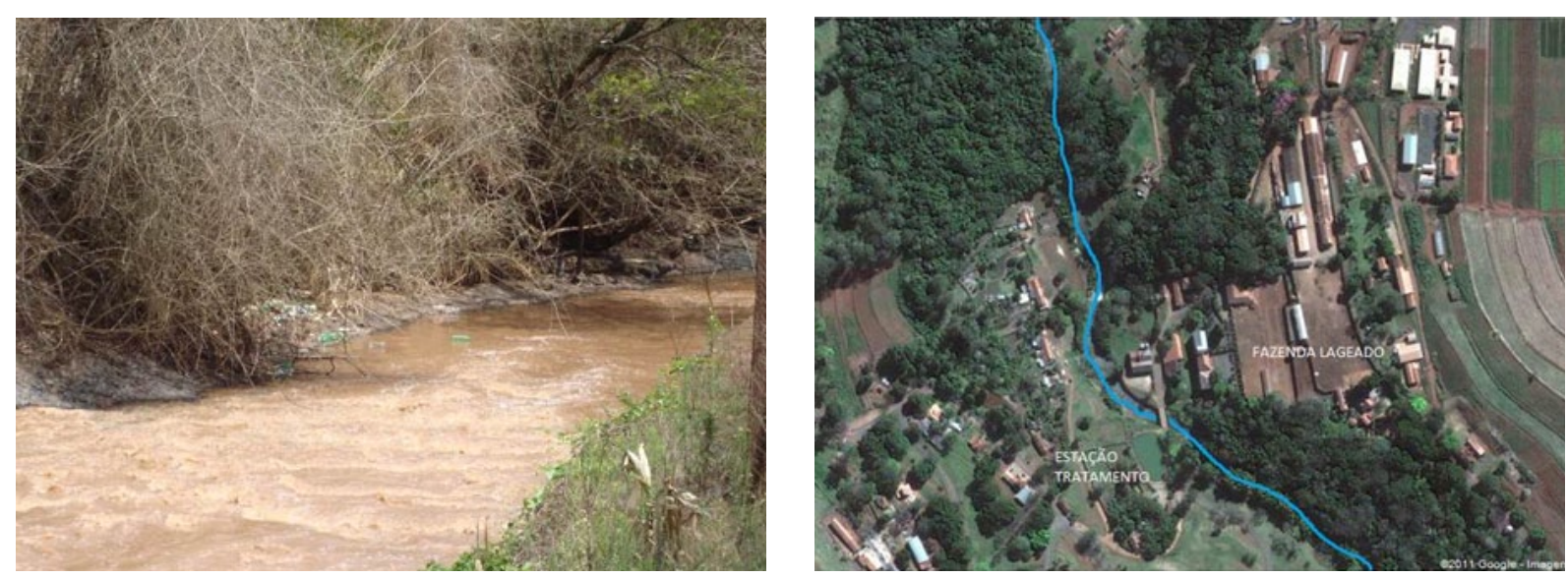

Figuras 3 e 4: Ribeirão Lavapés dentro da Fazenda Lageado. Fonte: imagem da autora Mara Pedroso e do Google modificada pelos autores.

Neste "sítio histórico", as instalações antigas estão em uso, como moradias, sediando núcleos e unidades de serviço. A "Casa Grande" é, atualmente, parcialmente ocupada pela Fundação de Estudos e Pesquisas Agrícolas e Florestais (FEPAF), entidade que congrega esforços no sentido de incentivar, viabilizar e agilizar projetos e convênios de pesquisa na FCA.

Pode-se observar no Museu do Café do Lageado e prédios históricos do entorno (Fig. 5 e 6), que a potencialidade turística é forte, é um local de fácil acesso, com boa divulgação local e que encanta pela beleza e valor paisagístico e pelo cuidado na manutenção das construções históricas sem descaracterizá-las. Porém, com dificuldades da aplicação de eficiência energética e de saneamento nestes edifícios. O Museu tem também intuito educacional, pois reúne acervo documental e de peças e máquinas antigas, ligados à história do café na região.

Em visitas ao Campus pode-se observar que o turismo de aventura e turismo rural emergem como uma das principais atividades econômicas da região, constituindo-se como um marco na paisagem local e elemento indutor do ecoturismo. 

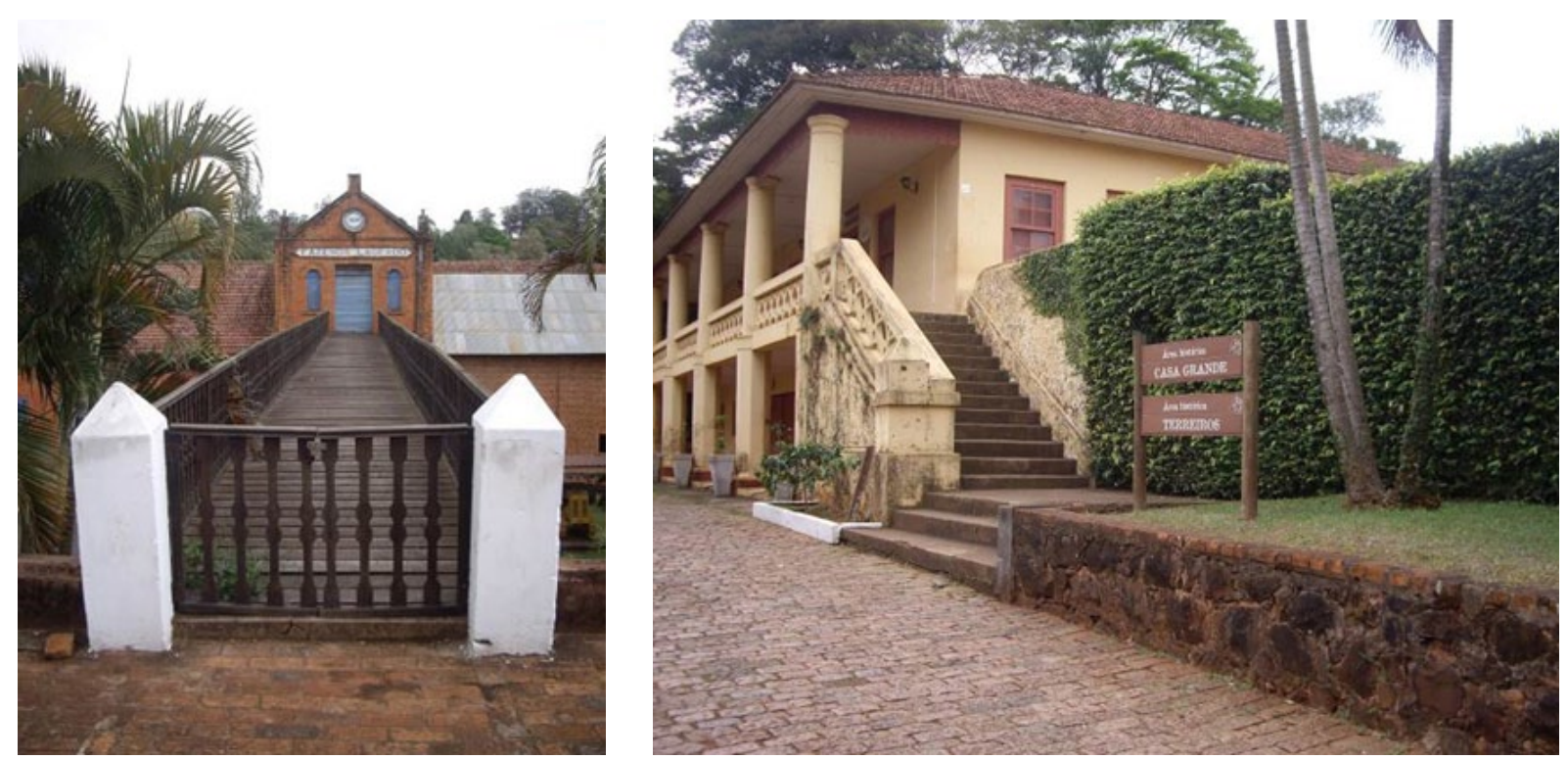

Figuras 5 e 6: Fazenda Lageado e Museu do Café. Fonte: imagem da autora Sirlei Bertolini Soares.

Analisando-se a rede viária externa ao campus, a rua de acesso à portaria I (Rua José Barbosa de Barros) tem boa sinalização e depara-se por esta via, com um esforço tímido, porém importante, de implantação de uma ciclovia que se inicia próxima da estação ferroviária e adentra a portaria do campus se extinguindo logo na entrada do mesmo. Esta ciclovia surpreende pela boa sinalização e conservação (Fig. 7a, 7b, 7c e 8), e é visível a consideração dos moradores locais, existe um parque em seu percurso, mas não se observa qualquer interligação desta ciclovia com outros polos de educação e cultura, notando-se uma subutilização.
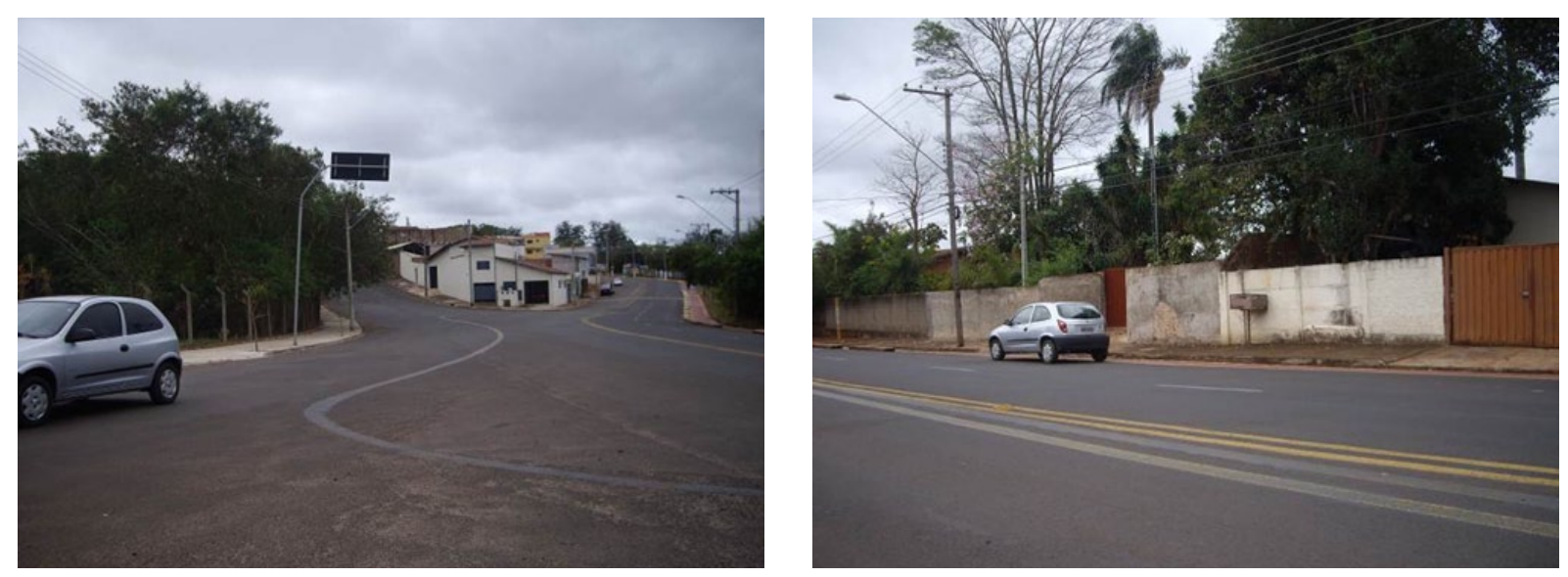

Figura 7: (a) e (b) ciclovia na Rua José Barbosa de Barros. Fonte: imagem da autora Sirlei Bertolini Soares. 

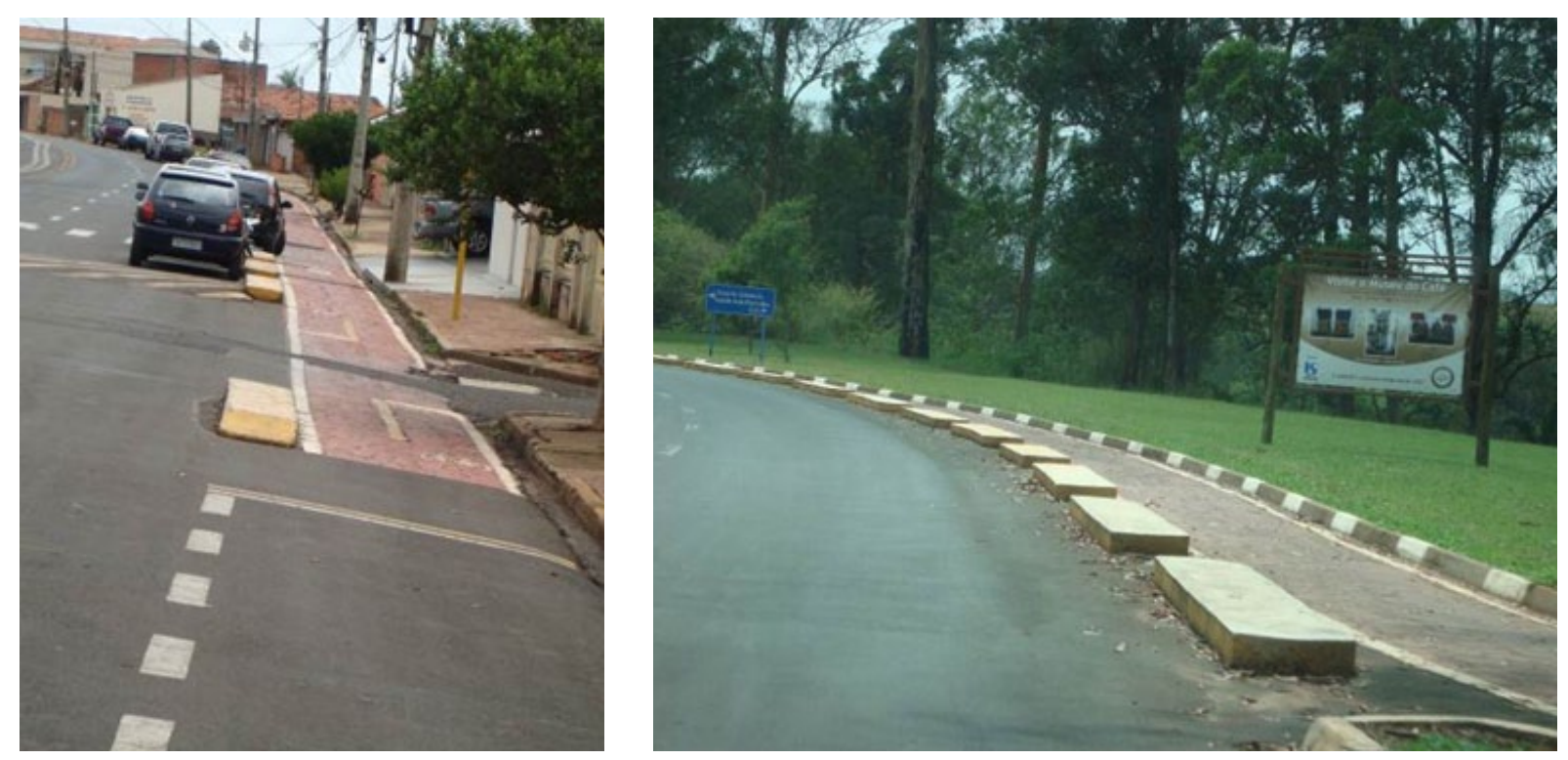

Figuras 7c e 8: (7c) Ciclovia na Rua José Barbosa de Barros. (8) Ciclovia dentro da UNESP. Fonte: imagem da autora Mara Pedroso.

A sinalização para o turista é formada por placas com formato uniforme e bem distribuídas, o que contribui para minimizar a poluição visual na região. A acessibilidade universal no Museu do Café do Lageado não foi planejada, até o momento. Nota-se presente o envolvimento comunitário no complexo, devido aos projetos de "sítio modelo" e turístico, e como existem moradores no local, encontra-se ali um pequeno modelo de gestão que trás uma influência estratégica para o Município de Botucatu. A coleta seletiva é incentivada para o turismo, com a implantação de lixeiras padrão.
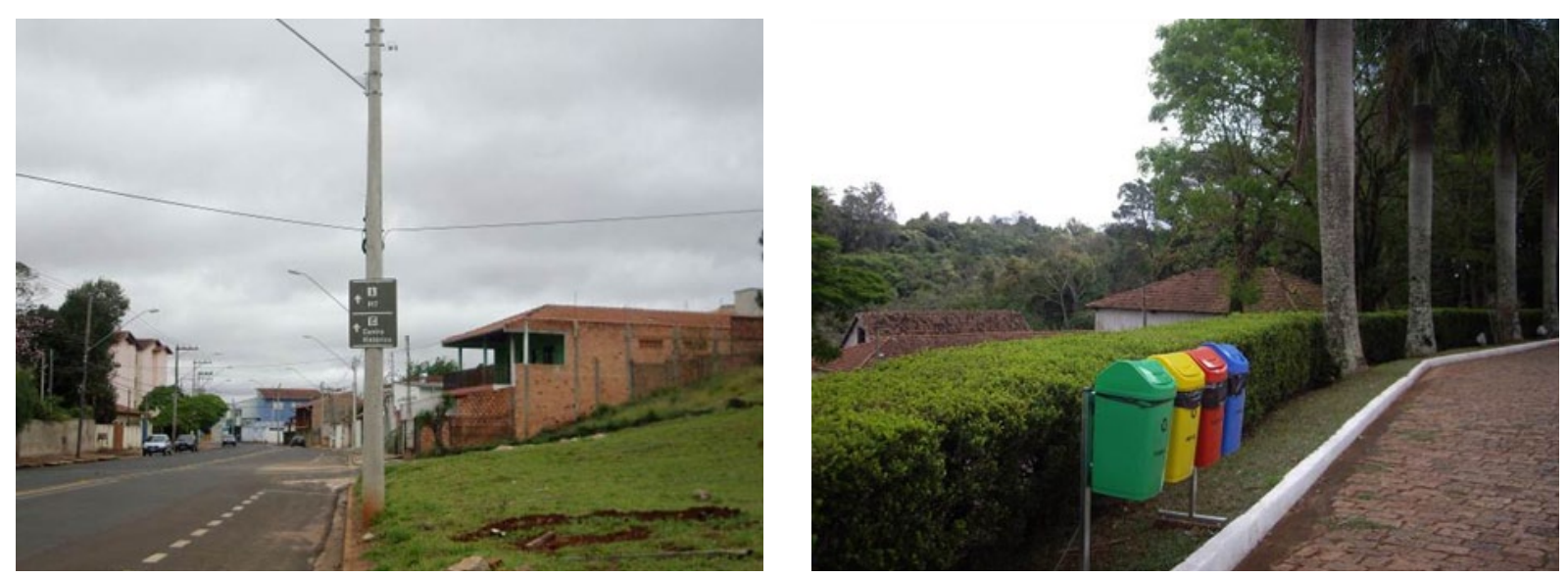

Figuras 9 e 10: Placas sinalização turista e lixeiras para coleta seletiva no Museu do Café. Fonte: imagem da autora Sirlei Bertolini Soares. 


\section{Objetivo}

O presente trabalho tem foco na importância do transporte alternativo como instrumento favorável às melhorias na mobilidade dos centros urbanos. Pretende-se trazer à luz fatores que levaram à degradação de muitas localidades urbanas e os projetos alternativos que emergem como alternativas favoráveis às melhorias.

Este estudo procura trazer ao leitor algumas notas sobre mobilidade nos centro urbanos, mostrando algumas de suas características, e suas consequências após a utilização das práticas urbanas aplicadas, incentivadas e difundidas amplamente durante o século XX. Assim, pretende-se abordar as consequências dos modelos que tinham como projeto principal a utilização do veículo motorizado particular.

Aponta-se o uso da bicicleta como uma alternativa eficaz para os males causados pela utilização em excesso do veículo motorizado particular e desta forma, o artigo procura elucidar as vantagens de se investir neste tipo de transporte com garantia não apenas no âmbito da saúde, mas como investimento com garantia de lucro.

Estas questões são colocadas de forma vinculada à necessidade de se implantar uma política de educação ambiental capaz de introduzir de forma gradativa, mas eficaz, as mudanças necessárias no comportamento dos agentes envolvidos para que se obtenham os resultados desejados.

Por fim, o artigo analisa os projetos de ciclovias propostos para o município de Botucatu, suas aplicações e resultados.

\section{DESENVOLVIMENTO E DEMONSTRAÇÃO DOS RESULTADOS}

O levantamento da situação atual permite estudar e planejar as atividades exercidas, tanto no âmbito urbano como no campus. Entre elas, a determinação do uso e ocupação do solo, indicação de áreas mais propícias à adequação de ciclovias e exploração do solo e principalmente no caso, do estudo, diretrizes para um projeto sustentável.

Com a proposta para recuperação das cabeceiras do Ribeirão Lavapés, pretende-se formar um grande corredor ecológico contabilizando-se cerca de dois quilômetros de recuperação florestal. Sendo assim a área torna-se de grande interesse para conservação e proteção e tem potencial para criação de novas áreas de preservação. 


\section{Projetos de Ciclovia para Botucatu}

Na prefeitura de Botucatu tramitam projetos para revitalização completa da Avenida Deputado Dante Delmanto importante corredor de ligação entre o campus da Unesp em Rubião Júnior e a região mais industrializada da cidade. O projeto da "Nova Dante", elaborado pela Secretaria Municipal de Planejamento, contempla ainda a construção de 2.850 metros de ciclovia. A construção de uma nova rotatória nesta Avenida organizará a distribuição do trânsito nas proximidades do "Distrito Industrial I", garantindo acesso rápido e seguro ao AME (Ambulatório Médico de Especialidades) e ao Centro de Recuperação Lucy Montoro, que serão instalados nas antigas dependências da Brashidro ${ }^{3}$.

Vários pedidos também foram abertos conforme vinculados no site da Câmara de Vereadores de Botucatu, pelo vereador André Rogério Barbosa (Curumim), para a implantação de uma ciclovia na Rodovia Antônio Butignolli - via que liga o Setor Norte ao Distrito de Rubião Júnior. A rodovia é também acesso ao Campus da Unesp-Rubião Júnior, onde cerca de 1500 veículos trafegam. Contudo, a via é ainda utilizada por inúmeros munícipes que utilizam bicicletas para se deslocarem pelo trajeto. "Essa situação tem oferecido muito risco de acidentes, por isso entendi ser interessante essa ciclovia naquela localidade", defende Curumim. A via possui pouco menos de dois quilômetros e representa uma via estratégica ao deslocamento à Universidade. Essa iniciativa já conta, inclusive, com projeto.

Nas imediações também foi implantado um novo bairro, o "Parque Residencial Santa Maria I", localizado na região Sul, às margens da Rodovia Gastão Dal Farra, contando com residências construídas pelo programa do Governo Federal "Minha Casa Minha Vida", que integra o programa municipal de habitação "Nosso Sonho", e são financiadas através da Caixa Econômica Federal (CEF), para famílias com renda de até três salários mínimos, contemplando ao todo quatrocentos e sete famílias, trazendo a tona, a preocupação com a mobilidade destas pessoas.

Normalmente, as vias principais constituem o caminho mais curto para os deslocamentos urbanos. Em muitas localidades a via principal é a única alternativa para uma rota ciclística. Segundo João Pompeu, estudante do Instituto de Biociências da Unesp de Botucatu, que esteve em reunião, em fevereiro deste ano, com o secretário munici-

3 Informações consultadas no site <www.botucatu.sp.gov.br> acessado em setembro/2011. 
pal de Planejamento, Caco Colenci, as Rodovias Antônio Butignoli e Domingo Sartori seriam boas alternativas para este deslocamento, mas como sua proposta envolve rodovias estaduais, o projeto ficou na dependência do DER (Departamento de Estradas de Rodagem) para ser aprovado.

Nesta reunião também se expos sobre o projeto de urbanização do Ribeirão Lavapés que contempla uma ciclovia na margem que liga o Lageado ao fim da Rua Amando de Barros, indo pela Estrada Municipal do Aeroporto até chegar a Rodovia Marechal Rondon.

Este projeto está afinado com a proposta de integração, promovendo a reestruturação urbana em torno desta importante microbacia. Resumindo: a junção da melhor rota ciclística em termos de topografia, recuperação de paisagem e condições hídricas do ribeirão.

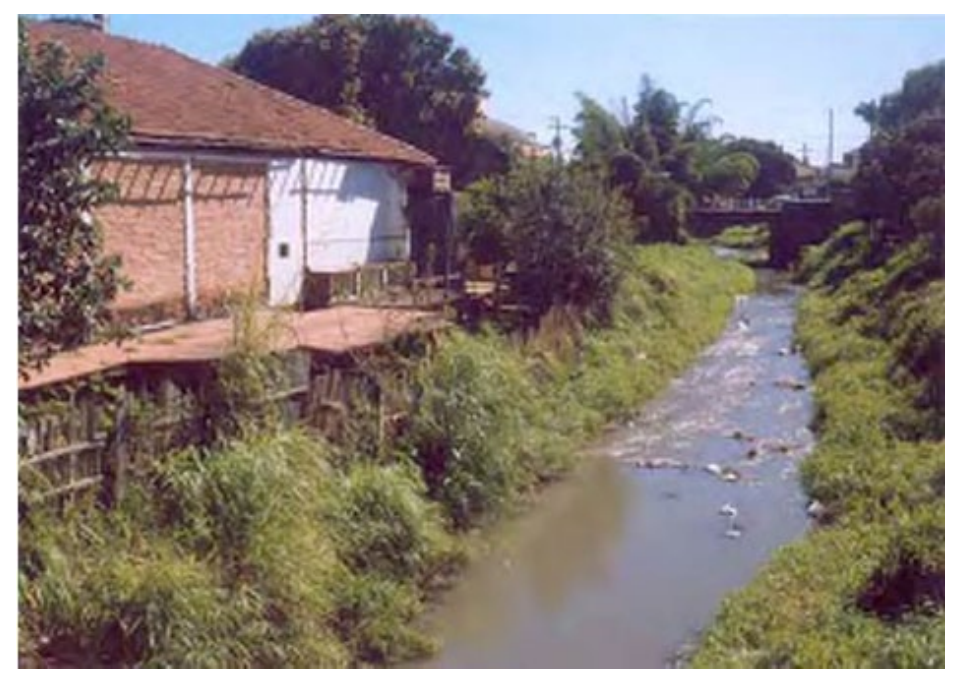

Figura 11: Construções irregulares às margens do Ribeirão Lavapés, no centro da cidade de Botucatu. Fonte: Imagem da autora Mara Pedroso.

\section{Possíveis Rotas Ciclísticas}

Trajeto 1: Ao longo do Ribeirão Lavapés desde o Campus Lageado da UNESP até a Rodovia Marechal Rondon, podendo ter um segundo trajeto margeando o rio até chegar a Av.Visconde de Rio Branco.

Trajeto 2 : Av. Visconde de Rio Branco atravessando a Rodovia Marechal Rondon seguindo até a Av. Domingos Sartori. 
Trajeto 1

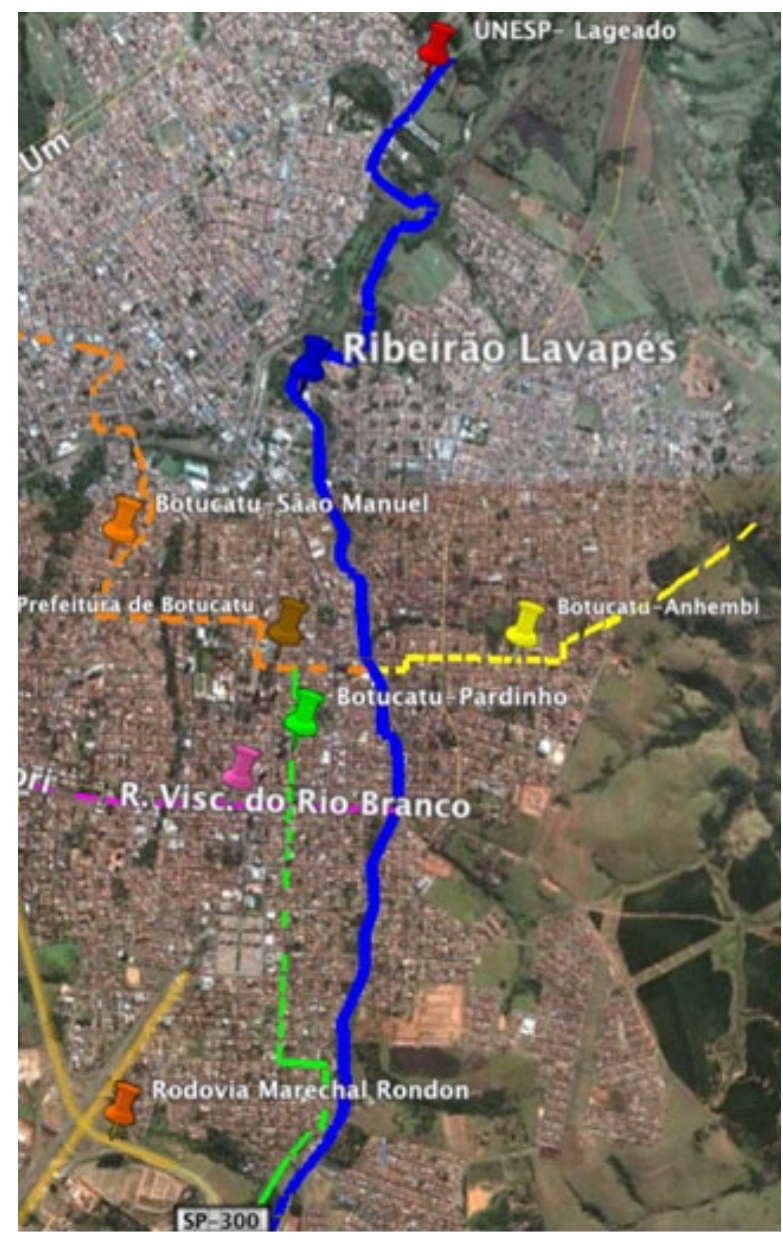

\section{Trajeto 2}

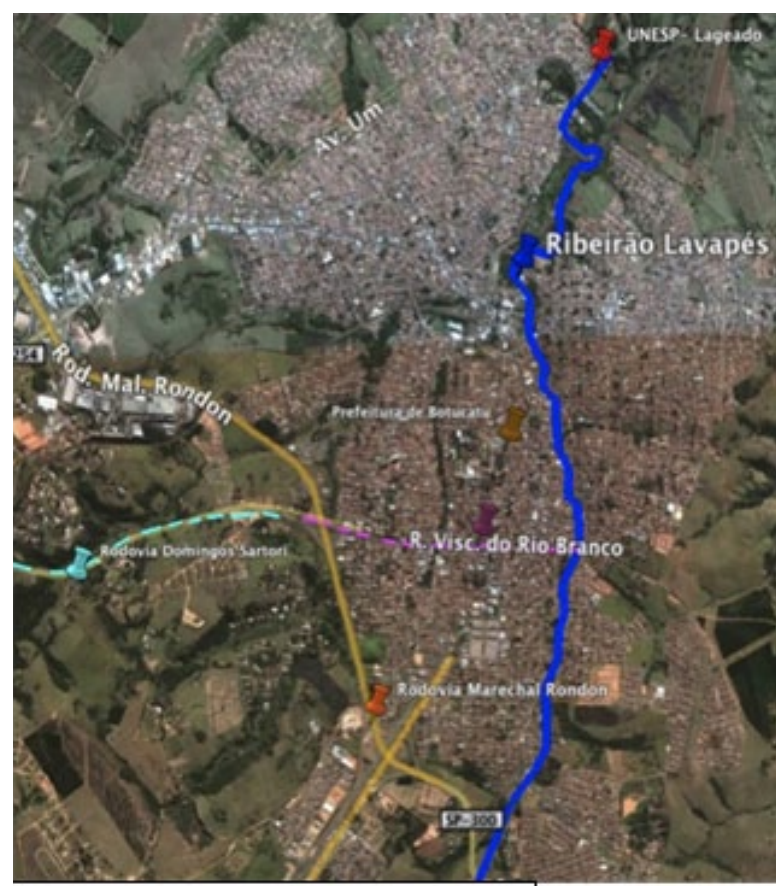

LEGENDA:

Av. Domingos Sartori

Trilha Botucatu-Anhembi

- - Av. Visconde do Rio Branco

$=$ Trilha Botucatu-Pardinho

$-=$ Trilha Botucatu-Săo Manue

Ribeirắo Lavapés

Figuras 12 e 13: Trajetos 1 e 2. Fonte: Google Earth, imagens modificadas pelos autores.

Trajeto 3 : Inclusão da rota Travessia Pólo Cuesta de Cicloturismo: saindo da rua Joaquim Amat em Botucatu seguindo pela Rodovia Domingos Sartori, com um total de $36 \mathrm{~km}$ de percurso.

Trajeto 4: Utilizando outra trilha, saindo da Rua Moraes de Barros- Botucatu encontrando com a margem do Lavapés, atravessando a Rodovia Dante Delmanto indo em direção a cidade de São Manuel, cerca de 35,9km.

Trajeto 5: Trilha ciclística Botucatu-Pardinho (parte da trilha global do Pólo Cuesta): com saída da Rua Moraes de Barros (Botucatu), passando pelo Bairro Residencial Parque Residencial Santa Maria 1, Rodovia Gastão Dal Farra e Bairro Demétria, seguindo para Pardinho. Perfazendo um total de $30,7 \mathrm{Km}$ de percurso. 
Trajeto 3

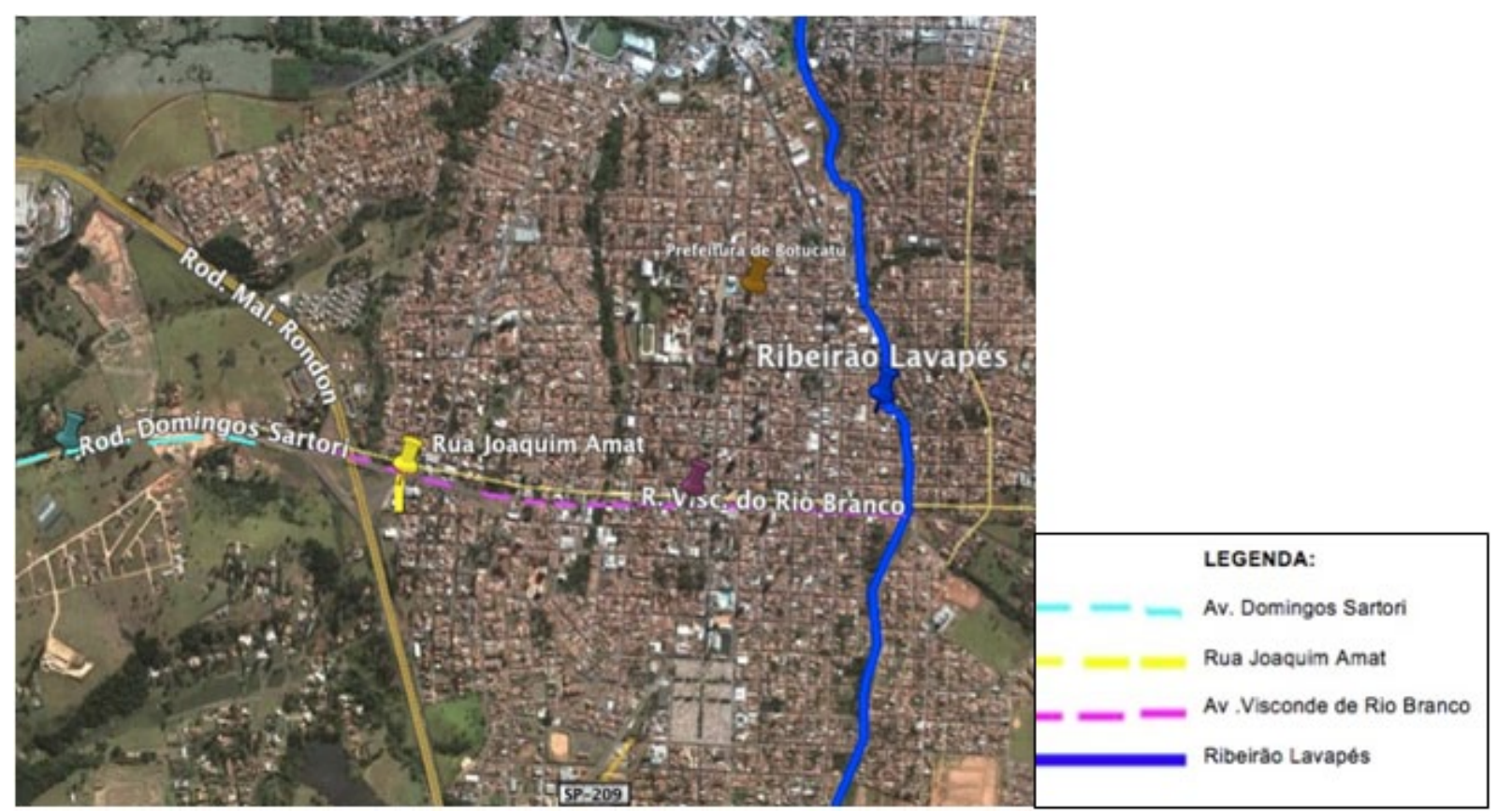

Figura 14: Trajeto 3. Fonte: Google Earth, imagens modificadas pelos autores.

\section{Trajeto 4}

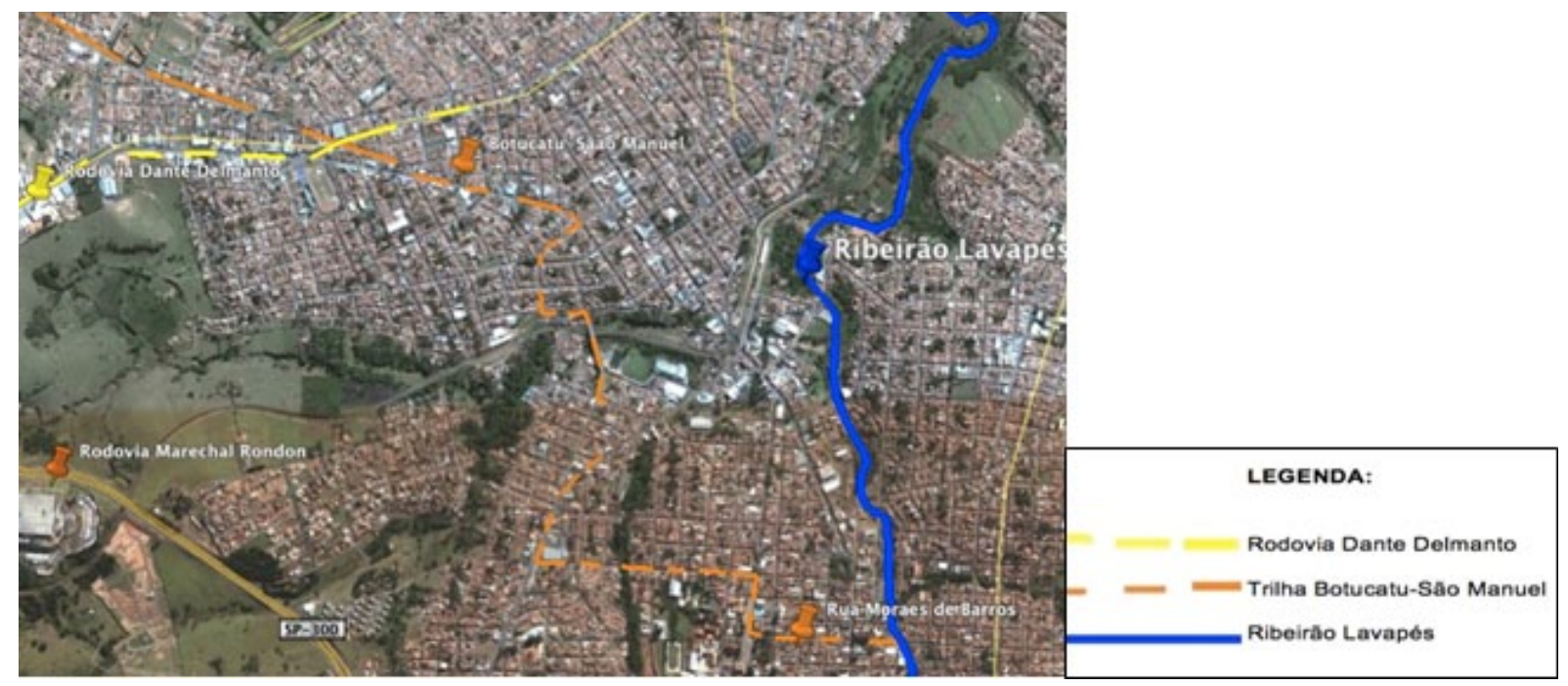

Figuras15: Trajeto 4. Fonte: Google Earth, imagens modificadas pelos autores. 


\section{Trajeto 5}

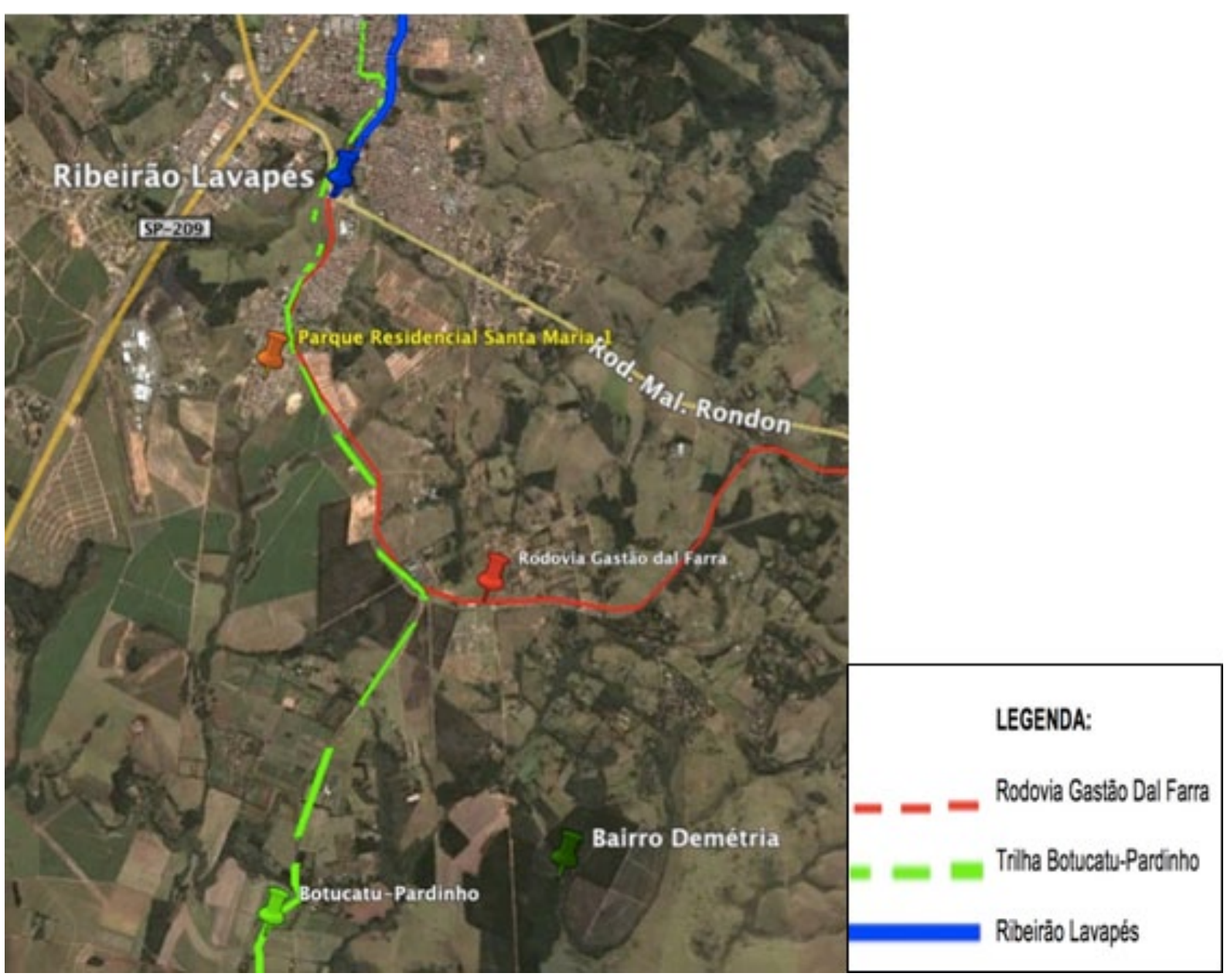

Figura 16: Trajeto 5. Fonte: Google Earth, imagens modificadas pelos autores.

Cada projeto de ciclovia, trilha ciclística, ou ciclo faixa, pensado isoladamente dentro dos municípios que formam o consórcio turístico Pólo Cuesta, contém o nítido intuito de possibilitar integração dos indivíduos na paisagem notadamente bela da região, também tem verdadeira vocação de promover a mobilidade sustentável no dia a dia da população local, como foi observado na importância da educação ambiental.

Apesar da falta de dados desta pesquisa com relação a bases e dados cartográficos, demonstra-se de forma empírica que a integração entre estes projetos cicloviários existentes é viável e de extrema importância para a funcionalidade da mobilidade sustentável. Esta integração teria o efeito de tornar a mobilidade nesta região em um importante projeto sustentável digno de ser referenciado e repetido em outras regiões com características semelhantes. 


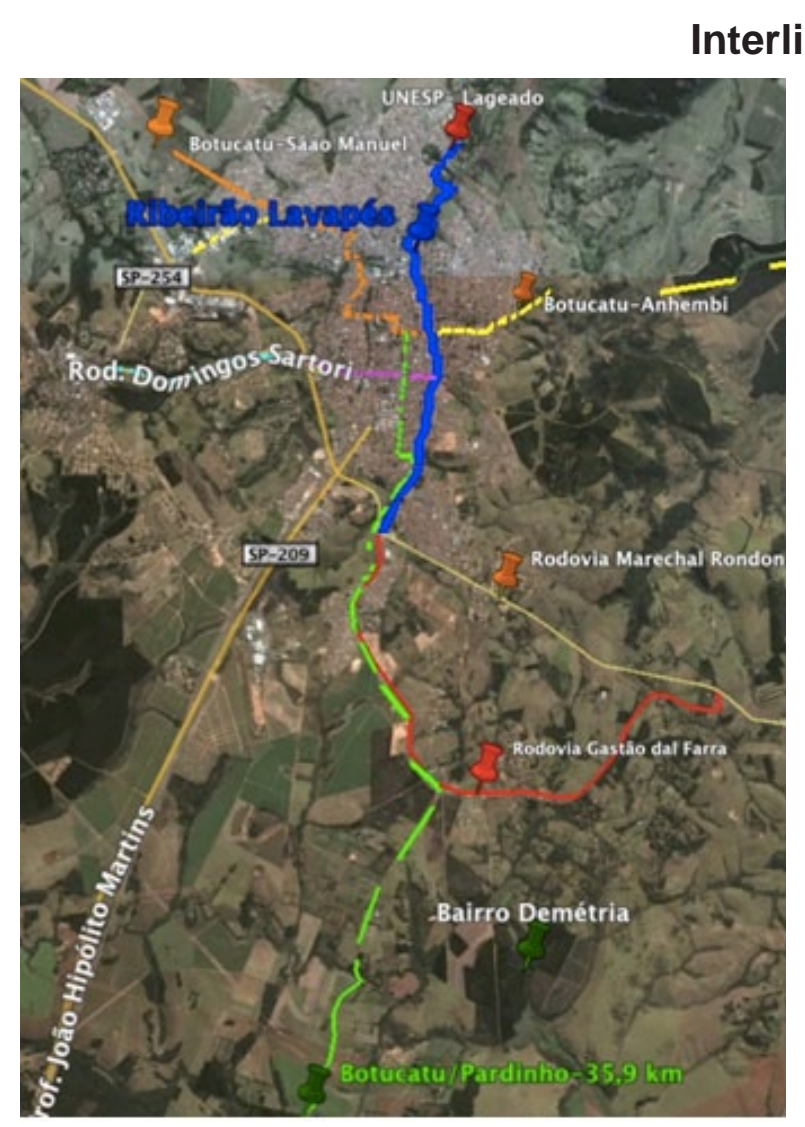

LEGENDA:

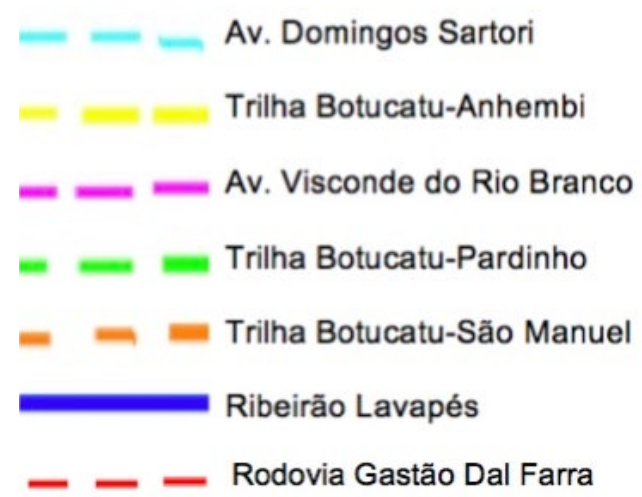

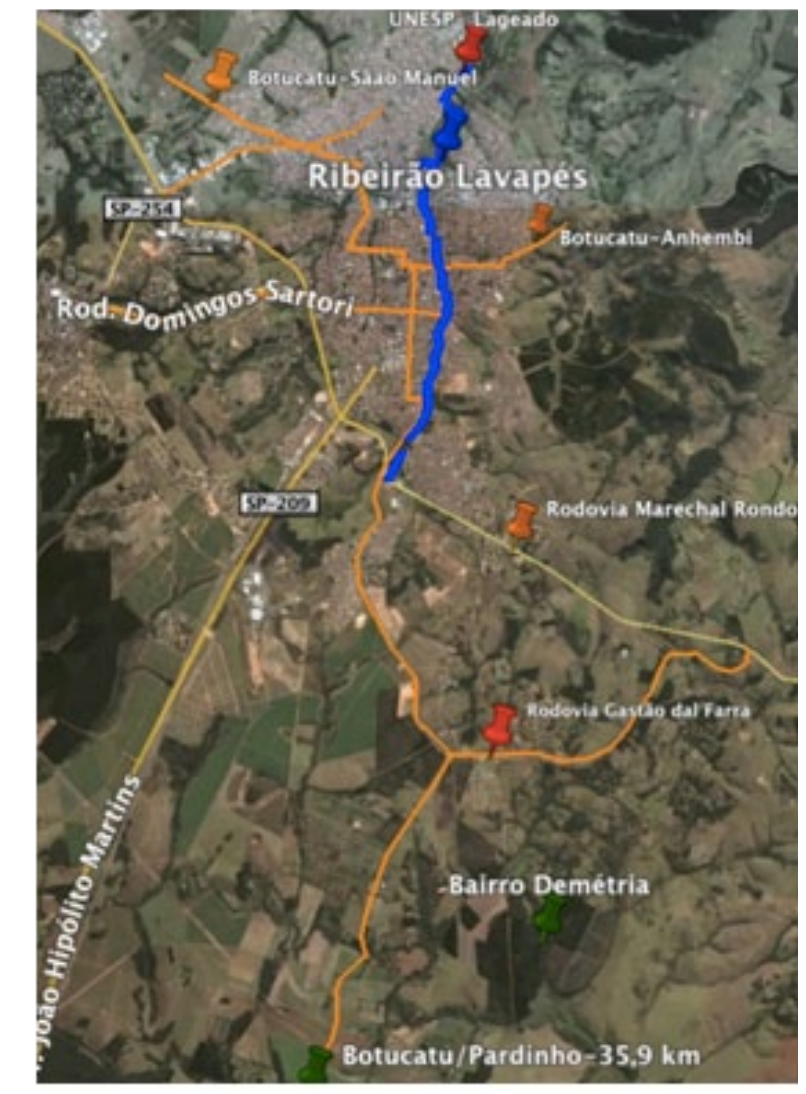

LEGENDA:

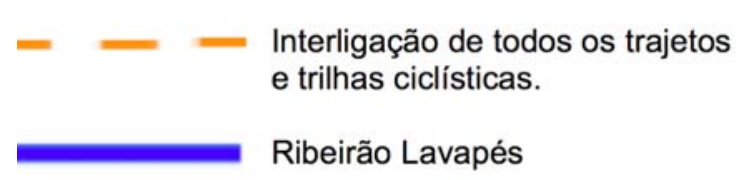

Figuras 17 e 18: Integração das ciclovias e trilhas. Fonte: Google Earth, imagens modificadas pelos autores.

\section{CONCLUSÃO}

Conclui-se que através da apropriação do espaço pela população local, pela mobilidade sustentável e também pelo resgate da paisagem do Ribeirão Lavapés, se promoverá ações de diagnóstico e monitoramento ambiental, melhorando as condições hídricas do ribeirão, mas tornando também a cidade mais acolhedora, fazendo com que os seus cidadãos se sintam pertencentes ao ambiente em que vivem. 
A população que utilizará a ciclovia poderá participar do monitoramento da qualidade ambiental do Lavapés, visualmente ou com auxílio de instrumentos - que podem ser fornecidos pela Universidade e pelos órgãos públicos, através de programas de educação ambiental. E cada ciclista poderá também ser um agente fiscalizador de esgotos irregulares lançados no ribeirão, maneira simples e eficaz de promover a manutenção e conservação das margens.

A ideia de buscar formas mais baratas e sustentáveis de transporte promoverá ganho de tempo diário gasto com deslocamento. A construção de estações intermodais poderá ser viabilizada pela Prefeitura em parceria com a iniciativa privada, integrando as bicicletas com outros sistemas de transporte, possibilitando estratégias de deslocamentos efetivamente viáveis e desenvolvendo maneiras de captar recursos para manutenção das ciclovias.

O fato da região do consórcio Pólo Cuesta abranger grande parte do aquífero Guarani e de belas paisagens naturais, com grande potencial turístico e de preservação da paisagem e das águas, torna em si, sua localização sustentável, mas a proposta da grande interligação para mobilidade sustentável em caráter setorial Regional para Local poderia seguir além do turismo e trazer, através da apropriação da população local, todos os benefícios de saúde, recuperação de áreas degradadas, inclusão social e até, enfim, o resgate da cidadania.

\section{REFERÊNCIAS}

ASSOCIAÇÃO BRASILEIRA DE NORMAS TÉCNICAS - ABNT, Rio de Janeiro. Normas ABNT sobre documentação. Rio de Janeiro, 2000. (Coletânea de normas).

BARROS, Z.X. Caracterização de bacias hidrográficas no mapeamento de solos mediante o uso de análise multivariada. Botucatu, 1988. 113p. Tese (Doutorado em Agronomia) - Faculdade de Ciências Agronômicas, Universidade Estadual Paulista.

BOTUCATU. Lei Orgânica do Município. Câmara Municipal de Botucatu, 1990. 82p.

CAMPOS, S. Fotointerpretação da ocupação do solo e suas influências sobre a rede de drenagem da bacia do rio Capivara, Botucatu (SP), no período de 1962-1972. Bo- 
tucatu, 1993. 164p. Tese (Doutorado em Agronomia) - Faculdade de Ciências Agronômicas, Universidade Estadual Paulista.

FIGUEIROA J. C. 2008. À beira do ribeirão lavapés. O ribeirão lavapés na formação histórica e econômica de Botucatu. In Bicudo, R. F., Orsi, A. C., Chinelato, F. C. S. LAVAPÉS, Água e vida, nos caminhos da educação ambiental. Sabep.

FRANÇA, Júnia Lessa et alii. Manual para normalização de publicações técnico-científicas. $6^{\text {a }}$ ed., rev. e aum., Belo Horizonte: Ed. da UFMG, 2003.

FRANCO, Maria Assunção Ribeiro. Planejamento ambiental para a cidade sustentável. São Paulo: Annablume, FAPESP, 2001.

INSTITUTO DE PESQUISAS TECNOLÓGICAS DO ESTADO DE SÃO PAULO - IPT. 1981a. Mapa Geológico do Estado de São Paulo. Escala 1:500.000. São Paulo. 2v. (IPT. Monografias, 6. Publicação, 1 184).

JACOBS, Jane. Morte e vida de grandes cidades. Trad.: Carlos S. Mendes Rosa; revisão da tradução: Maria Estela Heider Cavalheiro; revisão técnica: Cheila Aparecida Gomes Bailão São Paulo: Martins Fontes, 2000.

JACOBS, Jane. Dark age ahead. New York: Vintage Books, 2005.

KÖCHE, José Carlos. Fundamentos de Metodologia Científica: teoria da ciência e prática da pesquisa. 14a ed., Petrópolis: Vozes, 1997.

LEROY, Jean Pierre. PACHECO, Tânia. Democracia. FERRARO JÚNIOR, Luiz Antônio (org). Encontros e Caminhos: formação de educadoras(es) ambientais e coletivos educadores. Brasília, MMA, 2005.

Marcatto, Celso. Educação ambiental: conceitos e princípios: FEAM Belo Horizonte, 2002. (acessado em http://pt.scribd.com.br/doc/7028363/Educacao-AmbientalConceitos-Principios em novembro/2011)

MÜLLER, Mary Stela; CORNELSEN, Julce. Normas e Padrões para teses, dissertações e monografias. 5a ed. Londrina: Eduel, 2003. 
MORIN, Edgar. Os sete saberes necessários à educação do futuro. Cortez, 2000.

ORSI, A.C. Mapeamento dos parâmetros pedológicos e ambientais da bacia do Ribeirão Lavapés, em Botucatu - SP, utilizando técnicas de geoprocessamento. Dissertação de Mestrado, Faculdade de Ciências Agronômicas, UNESP, Campus de Botucatu, 112p, 2004.

SEARA FILHO,G. Apontamentos de introdução à educação ambiental. Revista Ambiental, ano 1, v. 1, p. 40-44, 1987

SEVERINO, Antônio Joaquim. Metodologia do trabalho científico. $22^{\mathrm{a}}$ edição, São Paulo: Cortez, 2002.

Caracterização Ambiental do Ribeirão Tanquinho. ONG S.O.S. CUESTA DE BOTUCATU, 2008. Relatório do projeto "Ribeirão Tanquinho Vivo - Mobilização e Educação Ambiental como modelo de Gestão Ambiental".

SILVA, K. C. Qualidade da água ao longo do Rio Capivara no Município de Botucatu - SP. 2007. 57 f. Dissertação (Mestrado em Agronomia/ Irrigação e Drenagem)-Faculdade de Ciências Agronômicas, Universidade Estadual Paulista, Botucatu, 2007.

SIMÕES, L.B. Avaliação das Áreas de Preservação Permanente da Bacia do Ribeirão Lavapés, Botucatu, SP, através de Sistema de Informações Geográficas (SIG-IDRISI). Botucatu, 1996. 144p. Dissertação (Mestrado em Agronomia) - Faculdade de Ciências Agronômicas, Universidade Estadual.

\section{Sites pesquisados}

http://bicicletanarua.wordpress.com

http://www.ondepedalar.com

http://www.polocuesta.com.br/portal/

http://www.botucatu.sp.gov.br 


\section{Principais documentos sobre Educação Ambiental}

Lei no. 9.795/99: Institui a Política Nacional de Educação Ambiental

Decreto no. 4.281/02: Regulamenta a Lei n. ${ }^{\circ}$ 9.795/99

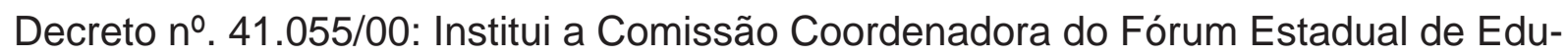
cação Ambiental de Minas Gerais

Conferência de Estocolmo

Carta de Belgrado

Recomendações de Tbilisi

Carta da Terra

Capítulo 36 da Agenda 21

Tratado de Educação Ambiental para Sociedades Sustentáveis e Responsabilidade Global Declaração de Thessalonik 